\title{
Erratum to: Modeling sequential R\&D investments: a binomial compound option approach
}

\author{
Bastian Hauschild $^{1} \cdot$ Daniel Reimsbach ${ }^{2}$
}

Published online: 26 August 2016

(C) The Author(s) 2016. This article is published with open access at Springerlink.com

\section{Erratum to: Business Research (2015) 8:39-59 DOI 10.1007/s40685-014-0017-5}

In the original publication, the authors are referring to a spreadsheet which should have been provided online as electronic supplementary material:

"Figure 5 in Appendix A shows the detailed spreadsheet (the MS Excel ${ }^{\mathrm{TM}}$ sheet containing all formulae is also provided as supplementary material to this article)."

Unfortunately, this supplementary material had been omitted in the original publication.

Open Access This article is distributed under the terms of the Creative Commons Attribution 4.0 International License (http://creativecommons.org/licenses/by/4.0/), which permits unrestricted use, distribution, and reproduction in any medium, provided you give appropriate credit to the original author(s) and the source, provide a link to the Creative Commons license, and indicate if changes were made.

The online version of the original article can be found under doi:10.1007/s40685-014-0017-5.

Electronic supplementary material The online version of this article (doi:10.1007/s40685-016-0038-3) contains supplementary material, which is available to authorized users.

Daniel Reimsbach

daniel.reimsbach@hhu.de;

http://www.rechnungslegung.hhu.de

Bastian Hauschild

bastian.hauschild@hhu.de

1 Department of Finance, University of Duesseldorf, Universitaetsstr. 1, 40225 Duesseldorf, Germany

2 Department of Accounting, University of Duesseldorf, Universitaetsstr. 1, 40225 Duesseldorf, Germany 